http://kitaibelia.unideb.hu/

ISSN 2064-4507 (Online) • ISSN 1219-9672 (Print)

(C) Department of Botany, University of Debrecen, Hungary

23 (2): 151-154.; 2018

DOI: $10.17542 /$ kit.23.151

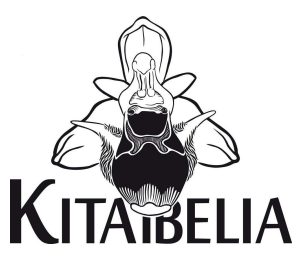

\title{
A Spiraea media Fr. Schm. Balaton-felvidéki előfordulásáról
}

\author{
VARGA Szabolcs ${ }^{1}$, SinIGLA Mónika² \& BAUER Norbert ${ }^{3 *}$ \\ (1) Pannon Egyetem, Fizika és Mechatronika Intézet, H-8200 Veszprém, Egyetem u. 10. \\ (2) Magyar Természettudományi Múzeum Bakonyi Természettudományi Múzeuma, H-8420 Zirc, Rákóczi tér 3-5. \\ (3) Magyar Természettudományi Múzeum Növénytár, H-1087 Budapest, Könyves Kálmán krt. 40. \\ *bauer.norbert@nhmus.hu
}

\begin{abstract}
About the occurrence of Spiraea media Fr. Schm. on the Balaton Uplands
Abstract - The presence of Spiraea media on the Balaton Uplands has high plant geographical importance, but the found location has not been known before its recent rediscovery. The Spiraea media was discovered on the Kopasz Hill (Felsőörs) growing in a closed Quercus cerris oak forest $(\sim$ Fraxino orni-Quercetum cerridis); which is a rather atypical habitat of the species. The appearance of blooming specimens and the rediscovery of the species is probably due to the cut of the neighbouring forest, which has resulted extra irradiation in the area. The 19th century military maps of the landscape show that the former vegetation of the area was characterised by the mosaics of rocky grasslandscrub-forest or rocky scrub rich patches being suitable for the species.
\end{abstract}

Keywords: flora, Fraxino orni-Quercetum cerridis, plant geography, relict, rocky scrubs

Összefoglalás - A Spiraea media Balaton-felvidéki előfordulása növényföldrajzi szempontból nagy jelentőségű adat, de a populáció pontos helye, mérete és élőhelye a közelmúltig ismeretlen volt. A felsőörsi Kopasz-hegyen a közelmúltban megtalált Spiraea media populáció atipikus élőhelyen, egy viszonylag zárt cseres-tölgyes erdőben ( $\sim$ Fraxino orni-Quercetum cerridis) található. Egyedeinek virágzása - és a faj megtalálása - feltehetően a szomszédos erdőrészlet letermelése következtében kialakult fénytöbbletnek köszönhető. A 19. századi katonai térképek alapján feltételezhető, hogy a terület korábbi vegetációjában jelen lehettek a faj számára kedvezőbb, fényben gazdag sziklás gyep-cserjés-erdő mozaikok, akár sziklai cserjések is.

Kulcsszavak: cseres-tölgyes, flóra, növényföldrajz, reliktum, sziklai cserjés

\section{Bevezetés}

A Spiraea media Fr. Schm. kontinentális flóraelem, Magyarországon északi-középhegységi súlypontú faj. A Dunától nyugatra a Dunazug-hegységben, a Gerecsében, a Mecsekben jellemző, egyéb előfordulásai (Mezőföldön, Villányi-hegységben) igen sporadikusak (ZóLYOMI 1936b, JÁvORKA \& Soó 1951, Soó 1966, BöLÖNI \& NAGY 1999). A Spiraea media Balatonfelvidéki, felsőörsi adata ZóLYOMI (1936b) térképmellékletén bukkan fel a szakirodalomban. A növény itteni felfedezése Jávorka Sándor nevéhez köthető, aki 1934. augusztus 13-án gyüjtött egy Spiraea media Schm. var. oblongifolia W. et K. példányt „In silvaticis vallis Malompatak" cédulafelirattal (BP 79952). Habár a herbáriumi cédulán településhatár nem szerepel, Jávorka más, ugyanezen a napon gyüjtött növénypéldányai alapján kiderítettük, hogy a lelő- 
hely-megnevezés valóban a felsőörsi Malom-patak völgyére vonatkozik. A Spiraea media hazai elterjedését bemutató későbbi szintézisekben említik, ill. ponttérképeken szerepel a felsőörsi előfordulás (pl. BARTHA \& MÁTYÁs 1995, BÖLÖNI \& NAGY 1999, BARTHA 2012), de ezek hátterében az idézett irodalmi adatok állnak (Bartha D. ex verb.), a pontos lelőhely egészen a közelmúltig ismeretlen volt. A felsőörsi Malom-völgyben az elmúlt években Sinigla Mónika és Varga Szabolcs egymástól függetlenül találtak rá a Jávorka által felfedezett Spiraea media állományra.

\section{Eredmények}

A Spiraea media felsőörsi populációja a Kopasz-hegy keleti lejtőjén, a Malom-völgy felett, de a völgyperem közelében, plakor helyzetben található (N47.01694 E17.94096 földrajzi koordináta 50 m-es körzetében). A lelőhely a 8973.4 CEU-kvadrátba esik. BARTHA \& MÁTYÁs (1995) térképe a délre eső szomszédos kvadrátot is megjelöli, de ott a faj előfordulását nem ismerjük. A faj felsőörsi lelőhelyéhez legközelebb fekvő ismert adatát, a Mezőföldről, Balatonkenese mellől közölték (GALAMBOS 2001). A szirti gyöngyvessző intenzív gyökérsarjképzése (ZAGYVAI 2006) miatt a felsőörsi Spiraea-populáció tényleges egyedszáma nehezen becsülhető, de a kb. 1/4 ha-os területen mintegy 500 bokor térképezhető. Az állomány a térképezés alapján legalább két nagyobb - egy 600 és egy $40 \mathrm{~m}^{2}$-es - foltból ( sarjtelepből) és néhány tucat, szórványosan megjelenő önálló egyedből áll. Az árnyasabb részeken a növény nem virágzik, de a szomszédos - a közelmúltban megbontott, majd letermelt - erdőrészlettel határos sávban virágzó példányok is előfordulnak (kb. az állomány 5\%-a).

A felsőörsi Spiraea media populáció egy csertölgy dominálta magról kelt tölgyes „Szálerdőben" található, felső-triász Füredi Mészkő alapkőzeten. A szirti gyöngyvessző e tölgyes foltban a cserjeszint egyik legjellemzőbb faja. Nagy termetű, 1-1,5 m magas példányai sem ritkák a területen. Az élőhely pontos dokumentálása érdekében a területen egy $20 \times 20$ m-es cönológiai felvételt készítettünk (A fajok borításértékeit \%-ban adjuk meg, az 1\% alatti értékek „+" jelzéssel szerepelnek. A felvétel dátuma: 2018.06.01.): A1: Quercus cerris 60, Quercus pubescens 20; A2: Fraxinus ornus 25, Tilia platyphyllos 5, Sorbus torminalis 3; B1: Ligustrum vulgare 15, Cornus mas 10, Acer campestre 8, Fraxinus ornus 5, Spiraea media 5, Lonicera xylosteum 1, Crataegus monogyna 1, Berberis vulgaris + , Crataegus laevigata + , Prunus spinosa +, Pyrus pyraster +, Rhamnus catharticus +, Tilia platyphyllos +, Ulmus minor +; B2: Cornus mas 5, Hippocrepis emerus 5, Acer campestre 3, Euonymus verrucosus 1, Hedera helix 1, Juniperus communis 1, Ligustrum vulgare 1, Sorbus torminalis 1, Carpinus betulus + , Cerasus avium +, Clematis vitalba +, Cornus sanguinea +, Euonymus verrucosus +, Quercus cerris +, Quercus pubescens + , Prunus spinosa + , Rosa canina + , Sorbus domestica + , Tilia platyphyllos + , Viburnum lantana +; C: Melica uniflora 8, Brachypodium sylvaticum 1, Galium mollugo agg. 1, Polygonatum latifolium 1, Ajuga reptans + , Arabis turrita +, Buglossoides purpureo-coerulea + , Campanula persicifolia +, Campanula rapunculoides +, Cephalanthera damasonium +, Chaerophyllum temulum +, Corydalis cava +, Dactylis glomerata +, Dictamnus albus +, Euphorbia cyparissias +, Geum urbanum +, Glechoma hirsuta +, Hypericum perforatum +, Lamium maculatum +, Orchis purpurea +, Polygonatum odoratum + , Primula veris + , Pulmonaria officinalis + , Securigera varia + , Trifolium alpestre + , Veronica chamaedrys + , Vincetoxicum hirundinaria +, Viola hirta +, Viola suavis + . Az állomány a cseres- és molyhos tölgyesek között áll, BoRHIDI et al. (2012) növénytársulás-rendszerében a Fraxino orniQuercetum cerridis Kevey \& Sonnevend in Kevey 2008 asszociációhoz áll a legközelebb, de közel sem tipikus. A Spiraea-populációt őrző cser dominálta folt feltűnő vonása a jelentős borítású cserjeszint és a viszonylag fajszegény, igen kis borítású gyepszint. A készített cönológiai felvétel fajösszetétele alapján is sejthető, hogy a terület korábbi vegetációja lényegesen 
eltérhetett a jelenlegitől. A Habsburg Birodalom második és harmadik katonai felmérés térképein (mapire.eu) jól látható, hogy a Kopasz-tető („Káposzta-tető” a harmadik katonai felmérés térképén) platóját a 19. század közepén és végén cserjés, cserjés-gyepes vegetáció borította, zárt erdők csak a Malom-völgyben és a szomszédos Királykúti-völgyben álltak.

Magyarországon a Spiraea media legjellemzőbb élőhelyei a ZóLYoмi (1936a) által leírt sziklai cserjések, sziklakibúvások, erdőszélek félárnyékos részei (BöLÖNI \& NAGY 1999). Az Északi-középhegységben és a Dunazug-hegység térségében a Spiraea-előfordulások jelentős része ilyen élőhelyen, törmeléklejtőkön, sziklás erdőszegélyeken (KLIKA 1938, HORÁNSZKY 1964, KovÁCS \& MÁTHÉ 1964, 1967, Simon 1972, 1977, VoJTKó 1990, NAGY \& ZENTAI 2001) található. Bokorerdőkben is jellemző, a fontos Aceri-Quercion karakterfajok egyike (JAKUCS 1961). A felsőörsi szirti gyöngyvessző állomány jelenlegi élőhelye tehát nem tipikus, de a szűkebb terület korábbi vegetációs képében biztosan jelen lehettek a faj számára optimálisabb, fényben gazdagabb erdő-cserjés mozaikok, akár sziklai cserjések. A cseres-tölgyesben található sziklakibúvások, sziklapadok mellett ezt bizonyítja, hogy a Malom-völgy sziklás peremein a Cotoneaster niger és a C. integerrimus is számos ponton megjelenik, de a Rosa spinosissima is előfordul a völgyben. Soó (1966) a sziklai élőhelyeken túl a cseres-tölgyeseket és az erdőspusztaréteket is a jellemző élőhelyei között sorolja fel. FARKAS \& Kun (1998) szerint a Tolnai-Mezőföldön sztyepcserjésben megtalált szirti gyöngyvessző populáció eredeti élőhelye a „felnyíló koronaszintű löszplató- és löszlejtő-erdő” lehetett.

BöLÖNI \& NAGY (1999) hangsúlyozzák, hogy a fajjal kapcsolatos legnagyobb természetvédelmi probléma a vadrágás. A felsőörsi állomány ebből a szempontból viszonylag kedvező helyzetben van, a vadrágás a területen - valószínúleg a kirándulóturizmus zavaró hatásának köszönhetően - kisebb mértékben jellemző. A felsőörsi állomány egy kisebb része a szomszédos, letermelt erdőrészletben található, ahol az erdőfelújítást segítő vadvédelmi kerítés mentén elvégzett vegyszeres gyomirtás veszélyezteti az állományt. A populáció előfordulásáról tájékoztattuk a Balaton-felvidéki Nemzeti Park Igazgatóságot és az erdőgazdálkodót, így az állomány megőrzése biztosítottnak látszik.

\section{Köszönetnyilvánítás}

Az állomány feltérképezésében Mészáros András (BfNPI, Csopak) nyújtott segítséget, a régi felsőörsi Spiraea-adathoz kapcsolódó korábbi publikációk forrásaival kapcsolatos tájékoztatásért Bartha Dénes professzor úrnak (Soproni Egyetem, Sopron) tartozunk köszönettel. A herbáriumok ellenőrzésében Mihai Puşcaş (Babeş-Bolyai University, Kolozsvár) és Takács Attila (Debreceni Egyetem, Debrecen) nyújtottak segítséget, munkájukat hálásan köszönjük. Végül megköszönjük Galambos Istvánnak (Zirc) és Nagy Józsefnek (Szent István Egyetem Kertészettudományi Kar, Budapest) a dolgozat elbírálásában nyújtott hasznos tanácsait és észrevételeit.

\section{Irodalom}

BARTHA D. (1999): Magyarország fa- és cserjefajai. - Mezőgazda Kiadó, Budapest, 302 pp.

BARTHA D. (2012): Magyarország ritka fa- és cserjefajainak atlasza. - Kossuth Kiadó, Budapest, 352 pp. BARTHA D. \& MÁTYÁs Cs. (1995): Erdei fa- és cserjefajok elófordulása Magyarországon. - Sopron, 224 pp. BoRHIDI A., KEVEY B. \& LENDVAI G. (2012): Plant communities of Hungary. - Akadémiai Kiadó, Budapest, 544 pp. BöLÖNI J. \& NAGY J. (1999): Szirti gyöngyvessző (Spiraea media Fr. Schm.) - Tilia 7: 170-181.

FARKAS S. \& KUn A. (1998): Spiraea media Fr. Schm. a tolnai Mezőföldön (Colocense). - Kitaibelia 3 (2): 317. Galambos I. (2001): Adatok a Bakony-hegység flórájához II. - Folia Musei Historico-Naturalis Bakonyiensis 17: 7-20. 
HARGitAi Z. (1940): A Sárospataki előhegyek vegetációjához. - Acta Geobotanica Hungarica 3: 18-29.

HoRÁNSZKY A. (1964): Die Wälder des Szentendre-Visegráder Gebirges. - Akadémiai Kiadó, Budapest, 288 pp. JAKUCS P. (1961): Die phytozönologischen Verhältnisse der Flaumeichen-Buschwälder Südostmitteleuropas. - Akadémiai Kiadó, Budapest, 314 pp.

JÁVORKA S. \& Soó R. (1951): A magyar növényvilág kézikönyve I-II. - Akadémiai Kiadó, Budapest, 1120 pp.

KLIKA J. (1938): Xerotherme Pflanzegesellschaften der Kovacover Hügel in der Südslovakei. - Studia botanica čechica 18 (3): 435-465.

KovÁcs M. \& MÁTHÉ I. (1964): A Mátrai flórajárás (Agriense) sziklavegetációja. - Botanikai Közlemények 51 (1): 1-15.

KovÁcs M. \& MÁTHÉ I. (1967): Waldsteino-Spiraeetum mediae. - In: ZóLYomi B. (ed.), Guide der Exskursionen des Internationalen Geobotanischen Symposiums, Ungarn. Eger-Vácrátót 5-10 Juni 1967, pp. 15-16.

NAGY J. \& ZENTAI K. (2001): A Délnyugati-Börzsöny Spiraea-cserjéseinek florisztikai és cönológiai vizsgálata. - Kitaibelia 6 (1): 121-132.

Simon T. (1972): Die Pflanzengesellschaft der Felsenvegetation im Zempléner Gebirge. - Annales Universitatis Scientiarium Budapestinensis de Rolando Eötvös Nominatae 14: 133-158.

Simon T. (1977): Vegetationsuntersuchungen im Zempléner Gebirge. - Akadémiai Kiadó, Budapest, 350 pp.

Soó R. (1966): A magyar flóra és vegetáció rendszertani-növényföldrajzi kézikönyve II. (Synopsis systematico-geobotanica florae vegetationisque Hungariae II.) - Akadémiai Kiadó, Budapest, 655 pp.

VojTKó A. (1990): A Központi-Bükk déli előterének vegetációja. - Folia Historico-Naturalia Musei Matraensis 15: 27-36.

ZAGYVAI G. (2006): Fásszárú növények gyökérsarjképzése. - Erdészeti Lapok 141 (9): 277-279.

Zólyomi B. (1936a): A Pannóniai flóratartomány és az északnyugatnak határos területek sziklanövényzetének áttekintése. (Übersicht der Felsenvegetation in der pannonischen Florenprovinz und dem nordwestlich angrenzenden Gebiete) - Annales Historico-Naturales Musei Nationalis Hungarici 30: 136-174.

ZóLYомі B. (1936b): A Spiraea media Schmidt alakköre. - Kertészeti Szemle 8 (10-11): 129-130.

\section{Világháló oldalak}

Magyar Királyság (1819-1869) - Második katonai felmérés https://mapire.eu/hu/map/secondsurvey-hungary (Megtekintés dátuma: 2018.07.09.)

Habsburg Birodalom (1869-1887) - Harmadik Katonai Felmérés (1:25000)

https://mapire.eu/hu/map/thirdsurvey25000 (Megtekintés dátuma: 2018.07.09.)

Beérkezett / received: 2018. 08.13. • Elfogadva / accepted: 2018. 08. 27. 